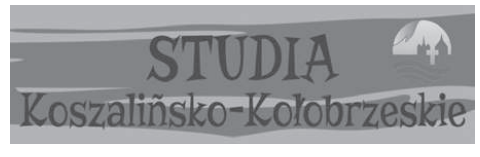

2016 nr 23

DOI: $10.18276 /$ skk.2016.23-20

Karol Jasiński ${ }^{1}$

\title{
LIBERALIZM A DOBRO WSPÓLNE
}

\begin{abstract}
Wstęp
Jedną z najbardziej rozpowszechnionych form życia państwowego, przynajmniej na terenie Ameryki Północnej i Europy, jest demokracja liberalna. Budowana jest ona na fundamencie następujących wartości: wolności, indywidualizmie, prawach obywatelskich, własności prywatnej oraz wolnym rynku. Mamy w niej do czynienia z dwoma zasadniczymi wersjami liberalizmu: klasycznym lub socjalnym. Przedstawiciele pierwszego nurtu (np. neoliberałowie, libertarianie, liberałowie konserwatywni) podkreślają, że nikt nie powinien zakłócać wolności jednostki, o ile ta nie stanowi zagrożenia dla innych. Postulują oni ponadto ograniczenie roli instytucji państwowych do zapewnienie ludziom bezpieczeństwa i porządku. Zwolennicy natomiast socjalliberalizmu (np. lewica, centrolewica, „zieloni”) opowiadają się za interwencjonizmem państwa w celu ochrony ludzi najbiedniejszych. Podkreślają także potrzebę swobody obyczajowej, świeckości przestrzeni publicznej i wolności światopoglądowej.

Wspólną cechą liberałów jest to, że w imię wyznawanych wartości rezygnują oni z określania dobra wspólnego na forum społeczno-politycznym i koncentrują się jedynie na wskazaniu pewnych ogólnych procedur wspólnego życia. Taką postawę przyjmuje chociażby J. Rawls w swojej książce pt. Teoria sprawiedliwości, która jest klasycznym dziełem stojącym u podstaw tzw. liberalizmu proceduralnego. Rawls podkreśla w niej, że wystarczającym warunkiem urządzenia państwa jest podanie pewnych prostych zasad umożliwiających pokojowe współistnienie obywateli. Państwo powinno być jednocześnie bezstronne, czyli nie narzucać żadnej określonej koncepcji „dobrego życia”, w tym koncepcji dobra wspólnego. W związku z powyższym może nasuwać się następujące pytanie: czy brak konkretnej wizji dobra wspólnego nie jest przypadkiem istotnym mankamentem państwa liberalnego?

Poniższe analizy są z jednej strony próbą zaprezentowania zasadniczych założeń liberalnego proceduralizmu, z drugiej natomiast mają na celu pokazanie, że na gruncie życia społeczno-politycznego nie sposób obejść się bez jakiejś koncepcji dobra, w tym również dobra wspólnego.
\end{abstract}

1 Ks. dr Karol Jasiński, Katedra Prawa Kanonicznego i Filozofii, Wydział Teologii Uniwersytetu WarmińskoMazurskiegow Olsztynie, email: karoljasinski@op.pl. 


\section{Proceduralizm liberalizmu}

Wydaje się, że zasadnicze przekonanie zwolenników liberalizmu dotyczy prymatu sprawiedliwości wobec ideałów i wartości moralnych. Według nich społeczeństwo jest zorganizowane najlepiej według pewnych zasad, które nie zakładają żadnej określonej koncepcji dobra ${ }^{2}$. Zasady winny być zatem wyprowadzone i ugruntowane niezależnie od wartości ${ }^{3}$. Brak ich uzasadnienia poprzez odwołanie się do konkretnych wartości związany jest z przekonaniem, że w życiu społecznym występuje nieustanne ścieranie się różnych wartości i idei, podobnie jak w życiu gospodarczym rywalizują z sobą różne przedsięwzięcia ${ }^{4}$.

Owa neutralność liberalizmu wobec wartości polega ponadto, zdaniem W. Sadurskiego, na braku narzucania ludziom określonej moralności lub zmuszania ich do niej. Zasady moralne są bowiem tylko wtedy sensowne, gdy wynikają z wewnętrznych przekonań człowieka. Narzucanie ich odgórnie jest skazane z góry na niepowodzenie. Moralność jest zatem, według Sadurskiego, domeną każdego niezależnego podmiotu. Natomiast na forum państwa należy zgodzić się na wspólne reguły współżycia. Wymóg neutralności odnosi się zatem do państwa, a nie do obywateli. Nie wyklucza też osądzania jednych ludzi przez drugich. Tak rozumiana idea neutralności jest zgodna z tradycją i wspólnotą kulturową, która sięga swoimi korzeniami chociażby myśli J. Locke’a i I. Kanta ${ }^{5}$.

Tak rozumiany liberalizm charakteryzuje się niekiedy jako jeden z nurtów politycznych, którego przedstawiciele kładą nacisk na procedurę, a nie treść oraz unikają dokładnego określania celów. Zadowalają się jedynie ustalaniem formalnych reguł mających minimalizować ewentualne szkody. Takie jednak podejście wydaje się być niewystarczające. Oprócz formalizmu zasad wymaga się bowiem w życiu społeczności także ich treściowego komponentu ${ }^{6}$.

Powyższe podejście związane jest ze specyficzną koncepcją człowieka jako istoty znajdującej się w dystansie wobec wszelkich okoliczności i uwarunkowań. Pojawia się jednak pytanie, czy jest to w ogóle możliwe? Wydaje się bowiem, że żadna jednostka nie potrafi uwolnić się od określonych sytuacji swego życia, ponieważ jest uwarunkowaną istotą

2 Francis Fukuyama, Koniec człowieka. Konsekwencje rewolucji biotechnologicznej (Kraków: Znak, 2004), 161; Michael J. Sandel, Liberalizm a granice sprawiedliwości (Warszawa: Wydawnictwa Akademickie i Profesjonalne, 2009), 37.

3 Sandel, Liberalizm a granice, 51.

4 John Gray, Liberalizm (Kraków: Znak; Warszawa: Fundacja im. Stefana Batorego, 1994), 111. Niekiedy odróżnia się neutralność światopoglądową od aksjologicznej. Państwo zobowiązane jest to pierwszej z tej racji, że nie może nikogo dyskryminować lub faworyzować z racji posiadanych przekonań. Natomiast wydaje się niemożliwą sytuacja neutralności aksjologicznej, ponieważ państwo winno chronić pewne wartości podstawowe będące fundamentem demokratycznego i pluralistycznego państwa, por. Jarosław Gowin, Kościót po komunizmie (Kraków: Znak; Warszawa: Fundacja im. Stefana Batorego, 1995), 92-93.

5 Wojciech Sadurski, Liberałów nikt nie kocha. Eseje i publicystyka 1996-2002 (Warszawa: Prószyński i S-ka, 2003), 70-71.

6 Jerzy Szacki, Liberalizm po komunizmie (Kraków: Znak; Warszawa: Fundacja im. Stefana Batorego, 1994), 36. 
społeczną7. Uwarunkowanie to nie determinuje jednak człowieka całkowicie, zwłaszcza w odniesieniu do określonych wartości i norm, które nigdy w pełni go nie konstytuują ${ }^{8}$.

Główne tezy liberalizmu proceduralnego można sprowadzić zatem do dwóch twierdzeń. Według pierwszego pewne prawa jednostek są tak istotne, że nie wolno od nich odstąpić nawet w imię powszechnego dobrobytu. Według drugiego zasady sprawiedliwości nie odwołują się do jakiejkolwiek moralnej lub religijnej koncepcji dobrego życia9 ${ }^{9}$.

Tezy powyższe zdają się wykazywać związek z poglądami I. Kanta na temat podmiotu i prawa moralnego. Zauważył on, że pojęcia dobra i zła muszą być określone nie przed prawem, ale dopiero po nim i przez nie ${ }^{10}$. Prawo to ma swój fundament w rozumnym podmiocie posiadającym wolną wolę ${ }^{11}$. Według Kanta podstawą prawa jest więc autonomiczna istota ludzka, a społeczeństwo liberalne jawi się jako jedyna forma życia wspólnego, którą mogą zaakceptować ludzie będący celami samymi w sobie ${ }^{12}$.

Pierwszeństwo zasad prawa wobec wszelkich wartości moralnych akcentował także J.S. Mill, według którego prawo to posiadanie czegoś, co winno być bronione przez społeczeństwo. Roszczenie prawne ma charakter bezwarunkowy, a państwo ma je podjąć nie ze względu na jakieś abstrakcyjne wartości, ale raczej z racji jego użyteczności ${ }^{13}$.

J. Rawls, proponując własną teorię sprawiedliwości prawnej, ma na uwadze, w przekonaniu J. Graya, z jednej strony kantowską koncepcję człowieka jako bytu autonomicznego i rozumnego, z drugiej natomiast podejmuje polemikę z utylitarystycznym podejściem Milla ${ }^{14}$. Koncepcja Rawlsa oparta została na dwóch zasadniczych elementach, jakimi są „sytuacja pierwotna” i ,zasłona niewiedzy”. Pierwotna sytuacja równości jest tu odpowiednikiem stanu natury w tradycyjnej teorii umowy społecznej. Stanowi ona sytuację hipotetyczną polegającą na braku wiedzy ludzi odnośnie ich miejsca i statusu w społeczeństwie, ich talentów i uzdolnień. Poszczególne jednostki nie wiedzą też nic o swoich koncepcjach dobra. W punkcie wyjścia wszystko rozgrywa się więc za ,zasłoną niewiedzy"15.

Kolejnym krokiem Rawlsa nie jest jednak stworzenie jakiejś jednej konkretnej koncepcji dobra mającej służyć zaspokojeniu ludzkich pragnień i dążeń, ale raczej ukazanie warunku jej utworzenia w postaci zasady sprawiedliwości rozumianej jako bezstronność. Zasady sprawiedliwości i słuszności ograniczają więc racjonalne koncepcje własnego dobra i są wobec niego nadrzędne ${ }^{16}$.

Ludzie znajdujący się w sytuacji pierwotnej kierują się racjonalnością, zgodnie z którą dochodzą do dwóch zasad sprawiedliwości. Według pierwszej każdy winien mieć równe

\footnotetext{
7 Sandel, Liberalizm a granice, 49-50.

8 Sandel, Liberalizm a granice, 65.

9 Sandel, Liberalizm a granice, 26.

10 Immanuel Kant, Krytyka praktycznego rozumu (Warszawa: Wydawnictwo Naukowe PWN, 2004), 105.

11 Immanuel Kant, Ugruntowanie metafizyki moralności (Kraków: Zielona Sowa, 2005), 62.

12 Gray, Liberalizm, 67.

13 John Stuart Mill, Utylitaryzm. O wolności (Warszawa: Wydawnictwo Naukowe PWN, 2006), 72-73.

14 Gray, Liberalizm, 96.

15 John Rawls, Teoria sprawiedliwości (Warszawa: Wydawnictwo Naukowe PWN, 1994), 24.

16 Rawls, Teoria sprawiedliwości, 48-49.
} 
prawo do podstawowych wolności, które są możliwe do pogodzenia z wolnością innych osób. Druga zasada odnosi się do nierówności społeczno-ekonomicznych występujących wśród ludzi. Winny być one tak ułożone, aby wiązało się to z największą korzyścią dla ludzi najbardziej upośledzonych oraz z równą dostępnością urzędów i stanowisk na zasadzie równości szans. Do owych dwóch reguł sprawiedliwości odnoszą się dwie dodatkowe zasady: wolność może być ograniczona tylko w imię wolności innych oraz zasady sprawiedliwości mają pierwszeństwo wobec zasady użyteczności ${ }^{17}$.

Zdaniem M. Króla zasadniczą cechę sprawiedliwości stanowi dla Rawlsa bezstronność, której źródłem jest sytuacja pierwotna zwana ,zasłoną niewiedzy”. Jak jednak to rozumieć? Otóż zabieg ten może sprowadzać się do prostej symulacji, ale wówczas sprawiedliwość i całe życie społeczne stają się grą. Inną możliwością jest natomiast opowiedzenie się po stronie idealizmu, z którego nie ma już jednak przejścia do rzeczywistości ${ }^{18}$.

Hipotetyczność owej ,zasłony niewiedzy” sprawia, że Rawls dokonuje jedynie jakiegoś eksperymentu myślowego. Zdaje się on mieć na celu wyakcentowanie pełnej swobody wyboru określonej koncepcji dobra na gruncie sprawiedliwości, która nie narzuca ludziom żadnych ograniczeń ${ }^{19}$. Rawls poddaje jednocześnie krytyce doktryny teleologiczne, zwłaszcza utylitaryzm, które w niewłaściwy sposób ustalają relację między słusznością i dobrem. Nie powinno się, jego zdaniem, określać jakości naszego życia ze względu na dobro określone w niezależny sposób, ale należy raczej ustalić najpierw zasady rządzące warunkami kształtowania owego dobra i sposobem jego realizacji. Z tej racji należy przyznać pierwszeństwo słuszności ${ }^{20}$.

Człowiek moralny jest dla Rawlsa podmiotem posiadającym wybrane przez siebie cele i wartości. Jego zasadniczy wybór odnosi się do warunków pozwalających na ukształtowanie takiego sposobu życia, który wyrażałaby jego rozumną i wolną naturę ${ }^{21}$. Ekspresja tej natury możliwa jest wyłącznie dzięki działaniu zgodnemu z zasadami słuszności i sprawiedliwości, które mają zawsze priorytet ${ }^{22}$.

Według Rawlsa każdy może realizować swój własny projekt życiowy, o ile nie narusza on wymagań sprawiedliwości. Człowiek upoważniony jest do swobodnego wyboru własnej koncepcji dobra. Tym bardziej że różne są dobra dla poszczególnych jednostek i każda z nich może sobie zaplanować życie w sposób jej tylko odpowiadający, o ile tylko będzie on zgodny z regułami sprawiedliwości ${ }^{23}$. Do reguł tych można zaliczyć wolność słowa, prasy, stowarzyszeń, wyznania, posiadania, ponadto mechanizmy polityczne, które sprawiają, że wszelkie nierówności społeczno-ekonomiczne będą rozstrzygane na

17 Rawls, Teoria sprawiedliwości, 414-416; Robert Alan Dahl, Demokracja i jej krytycy (Kraków: Znak; Warszawa: Fundacja im. Stefana Batorego, 1995), 122, 124.

18 Marcin Król, Liberalizm strachu, czy liberalizm odwagi (Kraków: Znak; Warszawa: Fundacja im. Stefana Batorego, 1996), 46.

19 Rawls, Teoria sprawiedliwości, 349.

20 Rawls, Teoria sprawiedliwości, 755-756.

21 Rawls, Teoria sprawiedliwości, 757; Fukuyama, Koniec człowieka, 162-163.

22 Rawls, Teoria sprawiedliwości, 775-776.

23 Rawls, Teoria sprawiedliwości, 135, 609. 
rzecz ludzi najbardziej upośledzonych, a dostęp do wszelkich stanowisk będzie równy dla wszystkich ${ }^{24}$.

Człowiek u Rawlsa ma więc prawo do nietykalności w wyborze dobra indywidualnego, którego nie można go pozbawić ze względu na dobro społeczeństwa. Nie można ograniczać także jego wolności, motywując to wzrostem dobra innych osób ${ }^{25}$. Przyznanie bowiem prawa do wolności jednej osobie gwarantuje zachowanie maksymalnie jednakowej wolności dla pozostałych i wyznacza tym samym ramy sprawiedliwej polityce państwa ${ }^{26}$.

Zaprezentowana powyżej neutralność państwa liberalnego może mieć też pewien związek z preferowaną przez jej zwolenników koncepcją wolności negatywnej, czyli działaniem ukierunkowanym na usuwanie przeszkód, jakie może spotkać jednostka na drodze ku realizacji swoich celów. Przedstawiciele innych wizji państwa akcentują tymczasem koncepcję wolności pozytywnej, dzięki której człowiek winien osiągnąć konkretne dobro będące życiowym powołaniem jego i całej społeczności ${ }^{27}$.

Koncepcja sprawiedliwości jako neutralności stała się przedmiotem ostrej krytyki i doprowadziła do reinterpretacji przez Rawlsa swoich poglądów. Nie chce on przezwyciężyć różnych koncepcji dobra ani też wykazać ich fałszu. Powołując się natomiast na doświadczenie historyczne i ludzką refleksję, podkreśla, że nie można oczekiwać racjonalnego porozumienia między nimi. Poszczególne koncepcje wyrażają sposoby widzenia świata i naszego życia jako całości, z którymi związane są rozmaite intelektualne i emocjonalne przywiązania. Owa różnorodność bierze się z ograniczonych i odmiennych perspektyw, a nie tylko ze złej woli i rywalizacji. Sprawiedliwość jako bezstronność ma na celu z jednej strony uznanie owych różnic za trwały element życia społecznego, z drugiej natomiast określenie takiego charakteru urządzeń społecznych, który pozwoliłby docenić pewne korzyści płynące z owej różnorodności ${ }^{28}$.

W kontekście krytyki teorii sprawiedliwości trzeba też zauważyć, że Rawls i inni liberałowie, uchylając się od wypracowania koncepcji dobra wspólnego, nie chcą jednak unieważniać problematyki moralnej, ale pragną dać do zrozumienia, że w państwie współczesnym możliwe są różne jej ujęcia. Do rozstrzygania kwestii moralnych nie jest powołane, ich zdaniem, państwo, które musi wstrzymać się od zajmowania stanowiska wobec różnych światopoglądów. Zadaniem władzy jest wyłącznie takie ułożenie stosunków między ludźmi, aby wynikało z nich jak najmniej szkody. Liberałowie mają więc nie tyle niechęć do kwestii moralnych, ile raczej do ich regulowania za pomocą działań politycznych. Nie są też zwolennikami relatywizmu moralnego rozumianego jako traktowanie wszystkich koncepcji za równowartościowe. Chcą oni jedynie, aby każdy miał prawo do uznania swego poglądu za najlepszy i układania według niego swego życia

\footnotetext{
24 Rawls, Teoria sprawiedliwości, 28, 88, 107, 109.

25 Rawls, Teoria sprawiedliwości, 13.

26 Gray, Liberalizm, 72.

27 Szacki, Liberalizm po komunizmie, 241.

28 John Rawls, „Kantian Constructivism in Moral Theory”, The Journal of Philosophy 77, 9 (1980): 542.
} 
w ramach jednego państwa. Postulaty ich dotyczą więc nie samej moralności, ale raczej roli polityki wobec niej29.

\section{W poszukiwaniu dobra wspólnego}

Jak się jednak okazuje, sprawiedliwość nie musi być koniecznie związana z bezstronnością, ale można ją także łączyć z określonymi koncepcjami dobra. Zasady sprawiedliwości mogą bowiem obowiązywać dzięki ich ugruntowaniu w wartościach wyznawanych powszechnie w danej społeczności ${ }^{30}$. Zresztą sam Rawls podkreśla w swej późniejszej pracy pt. Liberalizm polityczny, że zasady sprawiedliwości jako bezstronności są nie tylko proceduralne, ale w oczywisty sposób także materialne. Zauważa też, że zwolennicy liberalizmu politycznego mogą głosić wyższość pewnych form życia moralnego oraz zachęcać do pielęgnowania określonych cnót moralnych (np. kooperacji). Ponadto w jego najgłębszym przekonaniu akcentowanie przez nich słuszności nie oznacza pomijania dóbr ${ }^{31}$.

Wydaje się, że próba łączenia sprawiedliwości z bezstronnością związana była z obecną w liberalizmie tendencją do odchodzenia od wartości tradycyjnych ${ }^{32}$. Ponadto zasada prymatu słuszności nad dobrem jest w liberalizmie praktyczną reakcją na fakt, że samo pojęcie dobra wspólnego jest wieloznaczne ${ }^{33}$. Ludzie różnią się bowiem w społeczeństwach demokratycznych poglądami na temat wartości i dóbr. Z tej racji lepiej szukać porozumienia w sprawie neutralnych pod tym względem zasad sprawiedliwości ${ }^{34}$. Wartości moralne uważa się ponadto za nieporównywalne i niewspółmierne. W związku z tym odwołanie się do nich w systemie demokratyczno-liberalnym musi prowadzić z konieczności do nierozstrzygalnych konfliktów, których źródłem jest konfrontacja stanowisk dotyczących dóbr i wartości w państwie liberalnym. Jedynym więc wyjściem jest takie zachowanie w sferze publicznej, które chroniłoby nas przed owymi sporami. Promowanie określonych wartości jest niedopuszczalne, ponieważ prowadzi do ich absolutyzacji, a tym samym zagrożenia porządku liberalnego. W tej sytuacji uprawianie polityki musi od nich abstrahować i winno być sprowadzone jedynie do funkcji technicznych związanych z obsługą mechanizmu publicznego oraz zażeganiem potencjalnych konfliktów poprzez odpowiednie decyzje podejmowane na podstawie określonych przepisów prawnych. Niewspółmierność wartości może zachodzić ponadto nie tylko w sferze publicznej, ale także na granicy życia prywatnego i publicznego. Każdy człowiek posiada bowiem własną hierarchię wartości. Tymczasem w sferze publicznej decyzje są podejmowane

29 Szacki, Liberalizm po komunizmie, 244-246; Andrzej Szahaj, Jednostka czy wspólnota? Spór liberałów z komunitarystami a ,sprawa polska” (Warszawa: Fundacja Aletheia, 2006), 260.

30 Sandel, Liberalizm a granice, 27.

31 John Rawls, Liberalizm polityczny (Warszawa: Wydawnictwo Naukowe PWN, 1998), 267-270, 282.

32 Szacki, Liberalizm po komunizmie, 216.

33 Michael Novak, Wolne osoby i dobro wspólne (Kraków: Znak, 1998), 237-238.

34 Sandel, Liberalizm a granice, 282. 
na bazie racjonalnego porównywania różnych wartości i dóbr. W wyniku tego światy prywatny i publiczny byłyby odrębne i kierowałyby się innymi regułami ${ }^{35}$.

$\mathrm{Z}$ tej racji z owych potencjalnych konfliktów rodziłaby się konieczność opracowania konkretnych reguł określanych mianem sprawiedliwości proceduralnej. W przypadku występowania odmiennych wizji dóbr u różnych osób pojawiłaby się potrzeba opracowania zasad umożliwiających ich wspólne życie w ramach jednego społeczeństwa. Związane byłoby to z powołaniem różnych instytucji mających doprowadzić do kompromisu między partnerami. Należałyby do nich między innymi sądy, media i część służb państwowych. W wyniku tego nastąpiłoby odejście od polityki moralności na rzecz polityki prawa $^{36}$.

W imię więc wzajemnego szacunku i zapewnienia owocnej współpracy byłoby niezbędne branie w nawias przekonań dotyczących dobra. Podkreślanie prymatu zasady sprawiedliwości wobec moralnych lub religijnych koncepcji dobra prowadziłoby jednak do problemu związanego z rozstrzyganiem na forum publicznym niektórych ważnych kwestii, np. aborcji ${ }^{37}$. Sam zresztą J. Rawls zauważył, że w przypadkach bardziej praktycznych sama sprawiedliwość proceduralna jest bardzo rzadka, a nawet chyba niemożliwa. Podkreślał on, że idealnej sprawiedliwości proceduralnej nie da się zrealizować ${ }^{38}$. $\mathrm{Na}$ innym jeszcze miejscu Rawls zwrócił uwagę, że jego teoria sprawiedliwości zakłada pewną teorię dobra dla człowieka. Jednak z racji szerokiego jej zakresu nie określił dokładnie, na czym powinno ono polegać ${ }^{39}$.

W społeczeństwie demokratycznym należy więc docenić wolność i równość ludzi, ale nie może to prowadzić do eliminacji z życia społecznego określonych wartości. Tym bardziej że niekiedy są takie sytuacje, w których trzeba w sposób wyraźny opowiedzieć się po stronie pewnych wartości i zająć określone stanowisko. To natomiast jest związane z przyznaniem pierwszeństwa jakiejś jednej określonej koncepcji dobrego życia ${ }^{40}$.

M. Sandel podkreśla w związku z tym, że koszty podejścia liberalnego okazują się być duże i dotyczą zwłaszcza sfery moralności i polityki. W wymiarze moralnym zależałyby one od wartości doktryn moralnych i religijnych, które należałoby odrzucić na bok. Najwyższe byłyby wówczas, gdyby w imię sprawiedliwości tolerowano zło moralne. Mając natomiast na uwadze aspekt polityczny, należałoby zauważyć, że doświadczenie niektórych państw (np. Stanów Zjednoczonych) pokazuje, że polityka demokratyczna nie może długo wytrwać, gdy oderwana jest od wartości moralnych ${ }^{41}$.

Może w tej sytuacji rację ma M. Król, który opowiada się po stronie liberalizmu, ale pod warunkiem, że związany jest on z poszukiwaniem prawdy o człowieku i społeczeństwie, a w konsekwencji budowaniu na niej całego życia w wymiarze prywatnym i publicznym. Wyraża natomiast swój sprzeciw wobec takiej wersji liberalizmu, którego

35 Król, Liberalizm strachu, 77-78, 88-89, 108.

36 Król, Liberalizm strachu, 80, 99.

37 Sandel, Liberalizm a granice, 291-294.

38 Rawls, Teoria sprawiedliwości, 123, 274.

39 Rawls, Teoria sprawiedliwości, 358.

40 Król, Liberalizm strachu, 18.

41 Sandel, Liberalizm a granice, 314-315. 
zwolennicy chcieliby jedynie zagwarantować człowiekowi wolność oraz rozwiązywać w sposób łatwy i bezbolesny wszelkie konflikty społeczne ${ }^{42}$. Wydaje się, że wszelkie prawa i uprawnienia przestają mieć jakąkolwiek substancję, jeśli nie odnoszą się do zasad i wartości moralnych. Jedynie formalna poprawność przestaje stanowić obronę, a niekiedy może nawet stać się zagrożeniem, jeśli opieramy się wyłącznie na procedurach $^{43}$. Jeśli wszystko to, co pionowe (między innymi moralność i religia), zostanie usunięte z życia publicznego, to wówczas nie bardzo będzie można uratować także poziomej płaszczyzny więzi społecznych ${ }^{44}$.

Procedury tworzone przez człowieka powinny więc respektować określony moralny porządek dobra. Przy czym warto odróżnić dwa sposoby rozumienia relacji między nimi. Wedle koncepcji liberalnej szacunek wobec moralnych przekonań ludzi przejawiałby się w odsunięciu ich na bok i nieuwzględnieniu w dyskursie politycznym. Prowadziłoby to jednak do podważenia wzajemnego zaufania między obywatelami i przedstawicielami liberalnej władzy. Lepszy wydaje się być inny model szacunku, który polegałby na respektowaniu owych przekonań, okazywaniu im zainteresowania, poddawaniu niekiedy słusznej krytyce, ale też ich uwzględnianiu w sytuacjach nieobojętnych dla ważnych kwestii politycznych ${ }^{45}$. Należałoby również wziąć pod uwagę szeroki zakres zobowiązań moralnych lub politycznych, które pochodzić mogą z natury, od Boga, rodziny, narodu czy tradycji i nie zależą wyłącznie od naszego wyboru ${ }^{46}$.

Filozoficznej refleksji nad sprawiedliwością nie da się zatem oddzielić od analiz nad naturą dobrego życia, a w aspekcie politycznym nie można prowadzić namysłu nad sprawiedliwością i prawem bez odwołania się do koncepcji dobra w danych kulturach i tradycjach ${ }^{47}$. Ponadto zwłaszcza w krajach budujących demokrację nie można podejmować zasadniczych decyzji bez dokonywania wyboru między określonymi wartościami ${ }^{48}$.

Polski historyk idei J. Szacki zauważa, że sam liberalizm wydaje się być swoistym projektem społeczeństwa i propozycją dobrego życia ${ }^{49}$. Był chyba tego świadomy jeden z twórców idei liberalnych - J. Locke. Podkreślał on bowiem, że nadrzędnym celem i dobrem będącym impulsem do łączenia się ludzi we wspólnoty jest zachowanie ich życia, wolności i własności ${ }^{50}$. D. Sepczyńska zwraca natomiast uwagę na to, że liberałowie również mówią o dobru wspólnym, które jest przez nich rozumiane nie tylko jako suma dóbr jednostkowych, ale także jako możliwość harmonijnego rozwoju jednostek

\footnotetext{
42 Król, Liberalizm strachu, 6.

43 Dahl, Demokracja i jej krytycy, 167; Król, Liberalizm strachu, 65.

44 Król, Liberalizm strachu, 64, 66.

45 Sandel, Liberalizm a granice, 316.

46 Michael J. Sandel, Democracy's Discontent. America in Search of a Public Philosophy (Cambridge: Harvard University Press, 1996), 322.

47 John Gray, Dwie twarze liberalizmu (Warszawa: Fundacja Aletheia, 2001), 34; Sandel, Liberalizm a granice, 278.

48 Gowin, Kościót po komunizmie, 73; Król, Liberalizm strachu, 82.

49 Szacki, Liberalizm po komunizmie, 19.

50 John Locke, Dwa traktaty o rządzie (Warszawa: Wydawnictwo Naukowe PWN, 1992), 252.
} 
lub zbiór zasad zapewniających pokojowe współistnienie i współpracę ludzi o odmiennych koncepcjach dobra ${ }^{51}$.

Może ma rację więc W. Kymlicka, kiedy podkreśla, że w deklaracji o bezstronności państwa nie tyle chodzi o odrzucenie dobra wspólnego, ile o interpretację tej idei. W społeczeństwie liberalnym byłoby ono wynikiem procedury sumowania preferencji, z których każda liczyłaby się jednakowo i byłaby zgodna z zasadami sprawiedliwości ${ }^{52}$. Zdaniem natomiast M. Króla liberalizm stanowi swoistą formę ideologii, w której na szczycie hierarchii wartości postawiono wolność wszystkich ludzi w możliwie największym stopniu, daną po to, aby mogli się oni doskonalićs ${ }^{33}$. W tej sytuacji, zdaniem Ch. Taylora, liberalizm nie może rościć pretensji do bezstronności, ponieważ sam jest „,walczącym wyznaniem"s4.

Wydaje się więc, że każda społeczność państwowa, także ta o charakterze liberalno-demokratycznym, ma lub winna mieć jakąś koncepcję dobra wspólnego będącą fundamentem jej istnienia i funkcjonowania. R. Dahl wyróżnia w tym kontekście dwa typy dobra wspólnego: dystrybutywny i organicystyczny. Według pierwszego ujęcia, występującego z reguły u liberałów, dobro wspólne można rozłożyć na dobra poszczególnych jednostek tworzących zbiorowość (wykluczony zostaje tu jednak egoizm poszczególnych osób). W drugiej natomiast koncepcji, podzielanej przez krytyków liberalizmu, podkreśla się, że dobro wspólne jest czymś więcej niż jedynie sumą jednostkowych interesów ${ }^{55}$. E.W. Böckenförde wyróżnia natomiast dwa istotne komponenty dobra wspólnego: statyczno-pryncypialny i dynamiczno-celowy. Pierwszą komponentę stanowi uznanie człowieka jako podmiotu oraz jego fundamentalnych praw, drugą natomiast dążenie do rozwijania warunków życia osobistego, duchowego, ekonomicznego czy kulturowego. Zwraca ponadto uwagę na to, że same demokratyczne formy i procedury podejmowania decyzji politycznych są częścią dobra wspólnego danej społecznościis6.

Na przestrzeni wieków różnie pojmowano ideę dobra wspólnego. Według zwolenników myśli Arystotelesa i Tomasza z Akwinu dobro wspólne posiada stronę obiektywną i subiektywną, czyli jednoczy ono wszystkich ludzi we wspólnym celu, który jest jednocześnie celem każdej jednostki. Dobro ma ponadto charakter finalistyczny i analogiczny. Polega ono na coraz pełniejszej aktualizacji potencjalności osobowej natury człowieka (poznawczych i wolitywnych), która w każdym indywidualnym przypadku dokonuje się w inny sposób ${ }^{57}$. Zdaniem natomiast S. Kowalczyka, który jest zwolennikiem odwołującej się do myśli Akwinaty koncepcji personalistycznej, dobro wspólne nie może być

51 Dorota Sepczyńska, Katolicyzm a liberalizm. Szkic z filozofii społecznej (Kraków: Zakład Wydawniczy „Nomos”, 2008), 259-260.

52 Will Kymlicka, Współczesna filozofia polityczna (Kraków: Znak; Warszawa: Fundacja im. Stefana Batorego, 1998), 230.

53 Król, Liberalizm strachu, 111-112.

54 Charles Taylor, The Politics of Recognition, w: Charles Taylor, Philosophical Arguments (Cambridge: Harvard University Press, 1995), 249.

55 Dahl, Demokracja i jej krytycy, 107, 109.

56 Ernst Wolfgang Böckenförde, Wolność - państwo - Kościót (Kraków: Znak, 1994), 250-252, 263.

57 Gerard Dogiel, Antropologia filozoficzna (Kraków: Instytut Teologiczny Księży Misjonarzy, 1992), 70-72; Mieczysław Albert Krąpiec, Ja - człowiek. Zarys antropologii filozoficznej (Lublin: Towarzystwo Naukowe KUL, 1974), 293-300, 307-313. 
ujmowane jako ilościowe sumowanie dóbr indywidualnych. Ma ono dwojaki wymiar: ontologiczny (społeczność jako zespół rozumnych i wolnych osób) i aksjologiczny (różnego typu wartości). Ponadto, według Kowalczyka, należałoby wyróżnić w strukturze dobra wspólnego dwa istotne elementy składowe: wewnętrzny i zewnętrzny. Pierwszy z nich ma charakter ontologiczno-aksjologiczny, tzn. integralny rozwój osoby ludzkiej i zespół niezbędnych do tego wartości (witalnych, ekonomicznych, poznawczych, moralnych, estetycznych, religijnych). Drugi element ma natomiast profil społeczno-instytucjonalny, czyli odnosi się do zespołu struktur, instytucji, warunków ekonomicznych i społecznych (prawodawstwo, władza, szkolnictwo, organizacja pracy). Warto przy tym zauważyć, że owe struktury i instytucje mają charakter instrumentalny wobec pierwszego, osobowego elementu dobra wspólnego ${ }^{58}$.

Wydaje się, że obecnie podobny pogląd podziela M. Novak. Podkreśla on bowiem, że dobro wspólne nie jest narzucane z góry. Dobrem tym, czyli celem wspólnoty, jest natomiast umożliwienie każdej osobie jej pełnego rozwoju osobistego w zakresie jej zdolności i cnót ${ }^{59}$.

W wieku XX wizję dobra wspólnego bazującą na arystotelesowskiej koncepcji celu rozpatrywanego w ramach społeczności odnowili komunitarianie. Jednym z pierwszych w ich gronie był A. MacIntyre. Jego zdaniem człowiek nie musi samodzielnie wybierać celów egzystencji, ponieważ te są określone przez wspólnotę, w której żyje, oraz jej tradycję. W tym kontekście pojawia się kategoria cnoty jako pewnej stałej dyspozycji do kierowania swego życia według wspólnotowej definicji dobra i zła ${ }^{60}$. Ponadto kategoria celu związana jest u MacIntyre'go z naturą ludzką, która domaga się realizacji ${ }^{61}$.

Podobnie widzi to Ch. Taylor, który podkreśla, że w naturze człowieka zawarty jest logos, a ona sama winna być rozumiana w ramach szerszego porządku nadającego jej znaczenie ${ }^{62}$. Ponadto Taylor podkreśla rolę społeczeństwa jako warunku poszukiwania dobra człowieka. To właśnie wspólnota języka oraz dokonywany w nim dyskurs pomiędzy jej członkami przyczynia się do wyartykułowania dobra i jego realizacji. Ponadto człowiek jest istotą z natury społeczną i z tej racji przynależność do określonej wspólnoty jest warunkiem jego godności osobowej oraz gwarancją jej urzeczywistnienia ${ }^{63}$.

$\mathrm{Na}$ rolę społeczności w określaniu dobra wspólnego zwraca też uwagę M. Walzer. Ujmuje on to zagadnienie $\mathrm{w}$ ramach rozważań nad sprawiedliwością dystrybutywną. Według niego nie może być w tym kontekście mowy o dobru jako takim, a jedynie

58 Stanisław Kowalczyk, Człowiek a społeczność. Zarys filozofii społecznej (Lublin: Wydawnictwo KUL, 2005), 234-237.

59 Novak, Wolne osoby, 109, 112, 133.

60 Alasdair MacIntyre, Dziedzictwo cnoty (Warszawa: Wydawnictwo Naukowe PWN, 1996), 37, 343; Alasdair MacIntyre, The Virtues, the Unity of a Human Life and the Concept of a Tradition, w: Liberalism and Its Critics, red. Michael J. Sandel (New York: New York University Press, 1984), 141-145.

61 MacIntyre, Dziedzictwo cnoty, 78-79.

62 Charles Taylor, Legitimation Crisis?, w: Charles Taylor, Philosophy and the Human Sciences. Philosophical Papers. t. 2 (Cambridge: Cambridge University Press, 1985), 257-259.

63 Charles Taylor, „The Nature and the Scope of Distibutive Justice”, w: Charles Taylor, Philosophy and the Human Sciences. Philosophical Papers. t. 2 (Cambridge: Cambridge University Press, 1985), 292; Agnieszka Kaczmarek, Nowoczesna autentyczność. Charles Taylor wobec dylematów współczesności (Poznań: Wydawnictwo Poznańskie, 2011), 158-159, 160, 162. 
o dobru społecznym, czyli mającym znaczenie dla pewnej grupy osób. To właśnie sposób życia wspólnoty ludzkiej decyduje, co jest dla niej dobrem w konkretnych warunkach jej bytowania. Wspólnotą tą może być miasto, kraj lub państwo, które przez dłuższy czas kształtują swoją materialną i duchową egzystencję ${ }^{64}$.

Zdaniem innego jeszcze przedstawiciela komunitaryzmu, A. Etzioniego, dobro społeczności polega na traktowaniu ludzi nie jako środków do celu, ale jako celów samych w sobie; nie jako fragmenty, ale jako całe osoby; jako członków wspólnoty powiązanej za pomocą uczuć i zaangażowania, a nie jako pracowników, handlarzy, konsumentów czy też obywateli. Podkreśla też, że konkretne formy owego dobra moralnego są wynikiem prowadzenia dialogu społecznego, w wyniku którego podlega zmianie moralna kultura ludzi ${ }^{65}$.

Na bazie powyższych wypowiedzi można chyba dojść do wniosku, że jakaś koncepcja dobra wspólnego jako fundamentu organizmu państwowego jest nieodzowna. Żadne bowiem społeczeństwo nie przetrwa długo bez niej. Jej brak może natomiast prowadzić do pojawienia się różnych form przymusu i anomalii społecznych. W tej sytuacji tradycje i ideały moralne stają się swoistym warunkiem prawdziwej wolności żyjącego w państwie człowieka ${ }^{66}$. Koncepcja dobra wspólnego wydaje się być potrzebna nawet w społeczeństwach demokratyczno-liberalnych, w których nie ma jednego określonego systemu wartości, ale występuje różnorodność sposobów życia poszczególnych jednostek ${ }^{67}$.

Warto też mieć na uwadze, że dobro wspólne powinno odznaczać się odpowiednimi cechami, do których można zaliczyć: godziwość dobra, możliwość jego redystrybucji, zmienność i zdolność do doskonalenia ${ }^{68}$.

\section{Zakończenie}

Powyższe analizy były z jednej strony próbą zaprezentowania zasadniczych założeń liberalnego proceduralizmu, z drugiej natomiast miały uświadomić, że na gruncie życia społecznego nie sposób obejść się bez jakiejś koncepcji dobra wspólnego.

Zwolennicy liberalizmu przekonani są o prymacie zasady sprawiedliwości rozumianej jako neutralność. Ich zdaniem ustalanie zasad sprawiedliwości w państwie demokratycznym powinno dokonywać się niezależnie od określonych wartości. W społeczności liberalnej mamy bowiem do czynienia $\mathrm{z}$ ich pluralizmem oraz nieporównywalnością. Państwo winno też gwarantować respektowanie praw jednostek, z których nigdy nie można rezygnować w imię dobra wspólnego. Zresztą w przekonaniu liberałów jedna koncepcja dobra wspólnego jako fundamentu całej wspólnoty państwowej jest niemożliwa. Zadaniem państwa jest jedynie zagwarantowanie każdemu prawa do korzystania z podstawowych wolności oraz takie rozłożenie ewentualnych nierówności, aby przynosiły korzyść ludziom najbardziej poszkodowanym. Każdy obywatel może w związku

\footnotetext{
64 Michael Walzer, Spheres of Justice (New York: Basic Books, 1983), 9, 28, 30.

65 Amitai Etzioni, The Third Way to a Good Society (London: Demos, 2000), 11, 34-37.

66 Gray, Liberalizm, 77-78.

67 Szacki, Liberalizm po komunizmie, 183.

68 Kowalczyk, Człowiek a społeczność, 237.
} 
z tym utworzyć swój własny projekt dobrego życia i realizować go, pod warunkiem że nie narusza on projektów innych osób. Dobre życie będące jego przedmiotem ma za każdym razem wyrażać rozumną i wolną naturę poszczególnych jednostek.

Wydaje się jednak, że sprawiedliwość na forum państwa nie musi być związana z neutralnością, ale raczej z jakąś konkretną koncepcją dobra wspólnego możliwą do przyjęcia przez ogół. Prymat sprawiedliwości jako neutralności prowadzi bowiem do problemów z rozstrzyganiem $\mathrm{w}$ ramach państwa niektórych ważnych kwestii, np. aborcji, małżeństw. Ponadto życie w wymiarze zarówno indywidualnym, jak i społecznym winno być budowane na fundamencie prawdziwego dobra, którego ludzie winni poszukiwać. Zadaniem wszelkich procedur państwowych jest wówczas respektowanie rozpoznanego porządku dobra. Koncepcji sprawiedliwości nie da się wobec tego oddzielić od jakiegoś ujęcia dobra wspólnego. Wydaje się zresztą, że sam liberalizm daje pewną propozycję dobrego życia, w której wolność jest wartością naczelną. Na przestrzeni wieków wypracowano różne koncepcje dobra wspólnego. Do najważniejszych należy teoria arystotelesowsko-tomistyczna, według której dobro wspólne polega na rozwijaniu potencjalności rozumnej i wolnej natury człowieka. Odżyła ona w wieku dwudziestym w poglądach niektórych komunitarian, którzy podkreślili zwłaszcza społeczny aspekt owej natury. Człowiek nie jest, ich zdaniem, zdany na samodzielne poszukiwanie dobra, ponieważ jest ono określone przez wspólnotę, w której on żyje w konkretnych warunkach. W tej sytuacji człowiek winien skupić się na wyrabianiu w sobie cnoty polegającej na życiu według dóbr oferowanych przez społeczność oraz rozwijania w ten sposób własnej natury (np. A. MacIntyre, Ch. Taylor, M. Walzer, A. Etzioni). Własną koncepcję wypracował też empirysta brytyjski J. Locke, według którego dobro wspólne polega na zachowaniu własności poszczególnych osób.

Widać więc, że rozwiązanie proponowane przez liberałów nie jest jedynym możliwym. Ponadto wydaje się ono niewydolne zwłaszcza w tych momentach, w których trzeba podjąć na forum państwa decyzję dotyczącą moralnego wymiaru życia człowieka. Wówczas okazuje się, że same formalne procedury są niewystarczające i rzeczą konieczną jest odwołanie się do określonej koncepcji dobrego życia. Wydaje się, że brak ujęcia dobra wspólnego w liberalizmie proceduralnym jest wynikiem jego bardziej fundamentalnych założeń. Zalicza się do nich zwłaszcza indywidualistyczne i egoistyczne rozumienie człowieka, dla którego życie w społeczności jest przypadkowe i prowadzi z konieczności do generowania różnych konfliktów. Ponadto liberałowie wykazują tendencję do myślenia hipotetycznego dotyczącego początków państwa i prawa (np. koncepcja stanu natury, sytuacji pierwotnej czy zasłony niewiedzy), które nie ma historycznych odpowiedników w rzeczywistości. Jest jeszcze jedna kwestia godna uwagi. Otóż podejście liberałów wydaje się być wewnętrznie sprzeczne, ponieważ z jednej strony rezygnują z podania jednej koncepcji dobra wspólnego, z drugiej natomiast w rzeczywistości ją wypracowują. Dobrem wspólnym dla wszystkich jednostek jest wolność, którą winni strzec i realizować.

Wszystko więc wskazuje na to, że nie da się uciec w państwie od ujęcia dobra wspólnego. Może warto byłoby powrócić do odwołania się w tej kwestii do pojęcia natury ludzkiej. Dobro wspólne polegałoby więc na rozwijaniu natury człowieka, do której cech istotnych należy rozumność, wolność i relacyjność. Przy wszystkich kontrowersjach 
związanych z tym pojęciem wydaje się, że takie rozumienie dobra wspólnego byłoby możliwe do przyjęcia przez większość obywateli, w tym przez J. Rawlsa, i stanowiłoby tym samym stabilny fundament państwa demokratycznego.

\section{Bibliografia}

Böckenförde, Ernst Wolfgang. Wolność - państwo - Kościót. Kraków: Znak, 1994.

Dahl, Robert Alan. Demokracja i jej krytycy. Kraków: Znak; Warszawa: Fundacja im. Stefana Batorego, 1995.

Dogiel, Gerard. Antropologia filozoficzna. Kraków: Instytut Teologiczny Księży Misjonarzy, 1992.

Etzioni, Amitai. The Third Way to a Good Society. London: Demos, 2000.

Fukuyama Francis. Koniec człowieka. Konsekwencje rewolucji biotechnologicznej. Kraków: „Znak”, 2004.

Gowin, Jarosław. Kościót po komunizmie. Kraków: Znak; Warszawa: Fundacja im. Stefana Batorego, 1995.

Gray, John. Dwie twarze liberalizmu. Warszawa: Fundacja Aletheia, 2001.

Gray, John. Liberalizm. Kraków: Znak; Warszawa: Fundacja im. Stefana Batorego, 1994.

Kaczmarek, Agnieszka. Nowoczesna autentyczność. Charles Taylor wobec dylematów współczesności, Poznań: Wydawnictwo Poznańskie, 2011.

Kant, Immanuel. Krytyka praktycznego rozumu. Warszawa: Wydawnictwo Naukowe PWN, 2004.

Kant, Immanuel. Ugruntowanie metafizyki moralności. Kraków: Zielona Sowa, 2005.

Kowalczyk, Stanisław. Człowiek a społeczność. Zarys filozofii społecznej. Lublin: Wydawnictwo KUL, 2005.

Krąpiec, Mieczysław Albert. Ja - człowiek. Zarys antropologii filozoficznej. Lublin: Towarzystwo Naukowe KUL, 1974.

Król, Marcin. Liberalizm strachu, czy liberalizm odwagi. Kraków: Znak; Warszawa: Fundacja im. Stefana Batorego, 1996.

Kymlicka, Will. Współczesna filozofia polityczna. Kraków: Znak; Warszawa: Fundacja im. Stefana Batorego, 1998.

Locke, John. Dwa traktaty o rzadzie. Warszawa: Wydawnictwo Naukowe PWN, 1992.

MacIntyre, Alasdair. Dziedzictwo cnoty. Warszawa: Wydawnictwo Naukowe PWN, 1996.

MacIntyre, Alasdair. The Virtues, the Unity of a Human Life and the Concept of a Tradition.

W: Liberalism and Its Critics, red. Michael J. Sandel. New York: New York University Press, 1984.

Mill, John Stuart. Utylitaryzm. O wolności. Warszawa: Wydawnictwo Naukowe PWN, 2006.

Novak, Michael. Wolne osoby i dobro wspólne. Kraków: Znak, 1998.

Rawls, John. „Kantian Constructivism in Moral Theory”. The Journal of Philosophy 77, 9 (1980): 515-572.

Rawls, John. Liberalizm polityczny. Warszawa: Wydawnictwo Naukowe PWN, 1998.

Rawls, John. Teoria sprawiedliwości. Warszawa: Wydawnictwo Naukowe PWN, 1994.

Sadurski, Wojciech. Liberatów nikt nie kocha. Eseje i publicystyka 1996-2002. Warszawa: Prószyński i S-ka, 2003. 
Sandel, Michael. J. Democracy's Discontent. America in Search of a Public Philosophy. Cambridge: Harvard University Press, 1996.

Sandel, Michael. J. Liberalizm a granice sprawiedliwości. Warszawa: Wydawnictwa Akademickie i Profesjonalne, 2009.

Sepczyńska, Dorota. Katolicyzm a liberalizm. Szkic z filozofii społecznej. Kraków: Zakład Wydawniczy „Nomos”, 2008.

Szacki, Jerzy. Liberalizm po komunizmie. Kraków: Znak; Warszawa: Fundacja im. Stefana Batorego, 1994.

Szahaj, Andrzej. Jednostka czy wspólnota? Spór liberatów z komunitarystami a „sprawa polska”. Warszawa: Fundacja Aletheia, 2006.

Taylor, Charles. Legitimation Crisis?. W: Charles Taylor, Philosophy and the Human Sciences. Philosophical Papers. T. 2. Cambridge: Cambridge University Press, 1985,

Taylor, Charles. The Nature and the Scope of Distibutive Justice. W: Charles Taylor, Philosophy and the Human Sciences. Philosophical Papers. T. 2. Cambridge: Cambridge University Press, 1985.

Taylor, Charles. The Politics of Recognition. W: Charles Taylor, Philosophical Arguments. Cambridge: Harvard University Press, 1995.

Walzer, Michael. Spheres of Justice, New York 1983.

\section{Streszczenie}

Artykuł dotyczy kwestii związanej z pewnym mankamentem liberalizmu, jakim jest brak koncepcji dobra wspólnego. Najpierw zostały zaprezentowane zasadnicze tezy liberalizmu, którego istotną cechą jest proceduralizm (sprawiedliwość społeczna polega na neutralności wobec dobra oraz oparciu się na umownych zasadach). Na tym tle pokazano, że istotną cechą państwa nie musi być neutralność, ponieważ prowadzi ona do problemów z rozstrzyganiem niektórych ważnych kwestii, np. aborcji, małżeństw. Ponadto życie człowieka oraz właściwe funkcjonowanie państwa winno zakładać jakieś ujęcie dobra wspólnego. Autor artykułu wspomina o czterech jego koncepcjach: liberalnej (dobrem wspólnym jest realizowanie indywidualnej wolności), arystotelesowsko-tomistycznej (dobro wspólne polega na rozwijaniu potencjalności rozumnej i wolnej natury człowieka), komunitariańskiej (związana z Arystotelesem, ale bardziej podkreśla społeczny aspekt, np. A. MacIntyre, Ch. Taylor, M. Walzer, A. Etzioni) oraz koncepcji J. Locke’a (dobro wspólne polega na zachowaniu własności poszczególnych osób).

Słowa kluczowe: liberalizm, procedury, dobro wspólne, państwo, człowiek

\section{Abstract \\ LIBERALISM AND COMMON GOOD}

The article concerns to the relation between liberalism and the concept of the common good. First, the theses of the theory of liberalism were presented, which essential feature is proceduralism (social justice is based on neutrality towards good and contractual rules). On this 
background, it was shown that an important feature of the state does not have to be neutral, because it leads to the problems in resolving some important issues, such as abortion and marriage. In addition, human life and the right functioning of the state should assume any recognition of the common good. The article mentions four of its ideas: liberal (the common good is the realization of individual freedom), the Aristotelian-Thomistic (the common good is to develop a rational and free potentiality of human nature), Communitarian (associated with Aristotle, but it rather emphasizes the social aspect, such as A. MacIntyre, Ch. Taylor, M. Walzer, A. Etzioni) and the concept of J. Locke (the common good is to maintain life, freedom and ownership of individual persons).

Keywords: liberalism, procedures, common good, state, man 